\title{
Nasjonale retningslinjer for forebygging av selvmord i psykisk helsevern - erfaringer og utfordringer videre
}

Ved Fredrik A. Walby og Ewa Ness

\begin{abstract}
Nasjonale retningslinjer for selvmordsforebygging ble utgitt av Sosial- og helsedirektoratet i 2008. Forfatterne av denne artikkelen var henholdsvis faglig sekretær og leder for arbeidsgruppa og skrev utkastet til retningslinjene. Vi har begge senere vært aktive i implementeringsarbeidet nasjonalt og lokalt. Basert på dette, og på en spørreundersøkelse til alle helseforetakene i Helse Sør-Øst, drøfter vi erfaringer med retningslinjene og videre utfordringer på dette området.
\end{abstract}

Hovedmålsetningen med retningslinjene var følgende (Sosial- og helsedirektoratet 2008 , s. 8):

- Bedre helsetjenesten for pasienter med selvmordsproblematikk ved å bidra til at det gis et standardisert og kvalitetssikret behandlingstilbud innen psykisk helsevern i hele landet

- Bidra til å redusere antall selvmord og alvorlige selvmordsfors $ø$ k blant pasienter i psykisk helsevern ved å sikre et forsvarlig tilbud til denne gruppen

- Styrke tilbudet om god oppfølging og ivaretakelse av pårørende til pasienter med selvmordsproblematikk og etterlatte etter selvmord

- Gjøre helsepersonell som har kontakt med selvmordstruede personer mer kompetente, effektive og trygge i å håndtere selvmordsrisiko

Oppsiktsvekkende nok er det i norsk forvaltning, blant Helseforetakene eller andre steder, i liten grad tilgjengelige data som kan brukes for å evaluere, eller i det minste belyse, effekten av retningslinjene. Omfattende forskning viser til en voldsomt $\varnothing \mathrm{kt}$ risiko for selvmord blant pasienter i psykisk helsevern (Walby 2008, Qin \& Nordentoft 2005). Tall fra Helsetilsynets meldesystem viser at antall meldinger som gjelder d $\varnothing$ dsfall på grunn av selvmord $\varnothing$ kte fra 76 i 2008 til 132 i 2011 (Helsetilsynet 2012). Det er samtidig kjent at det norske meldesystemet ikke fungerer tilfredsstillende (Rønneberg \& Walby 2008) bl.a. på grunn av manglende rapportering og usystematisk datainnsamling. Retningslinjene la betydelig vekt på å $\varnothing$ ke antallet selvmord som meldes til Helsetilsynet. Eventuelle endringer i meldte selvmord kan derfor ikke på noen måte brukes til å belyse eventuell effekt av retningslinjene, men kan istedenfor skyldes en bedre meldekultur, noe som i tilfelle er en $\varnothing$ nsket effekt.

\section{Spørreundersøkelse}

Gjennom undervisningsvirksomhet i mange helseforetak landet rundt er vårt inntrykk at retningslinjene i stor grad er kjent og brukt. Dette samsvarer også med funn fra Helsetilsynet i Oslo og Akershus sin oppsummering av tilsyn på DPS døgnenheter i 2010 hvor de konkluderer: "Vårt hovedinntrykk er at Nasjonale retningslinjer for forebygging av selvmord i psykisk helsevern virker implementert" (Medisinalmelding 2010).

I et fors $\varnothing \mathrm{k}$ på å innhente noe mer systematiske synspunkter på erfaringer med bruken av retningslinjene sendte vi ut en kortfattet spørreunders $\varnothing$ kelse til ti klinikkledere i Helse S $\varnothing r$ - $\varnothing$ st. Àtte av disse svarte. Unders $\varnothing$ kelsen besto av seks enkle spørsmål samt mulighet for å gi kommentarer i fritekst. Syv av åtte svarte at retningslinjene var godt kjent, og like mange at retningslinjene ble oppfattet som nyttige. Alle åtte rapporterte å ha skriftlige retningslinjer internt for selvmordsrisikovurdering. Alle hadde også interne rutiner for opplæring i risikovurdering. Fire av åtte svarte at selvmordsrisikovurderinger ble utført av både lege/psykolog og høgskoleutdannet personell. De fleste kommentarene i fritekstfeltene dreide seg om interne rutiner, eller mangel på slike, og om skillet i ansvar og oppgaver mellom lege/psykolog og annet personell. Vi spurte også spesifikt om forslag til tiltak for videre implementering av retningslinjene. Her dreide de fleste kommentarene seg om at man oppfattet retningslinjene som nyttige og som et godt utgangspunkt for utarbei- delsen av lokale prosedyrer. Basert på denne enkle spørreunders $\varnothing$ kelsen kan det synes som om retningslinjene er godt mottatt og tatt i bruk. Imidlertid sier klinikkledelsens svar i begrenset grad noe om hvorvidt dette også er gyldig i det daglige kliniske arbeidet.

Basert på ovenstående må vi derfor kunne konkludere med at flere forhold kan tyde på at retningslinjene er kjent og tatt i bruk. Imidlertid lar ikke spørsmålet om retningslinjene har hatt selvmordsforebyggende effekt seg besvare basert på kunnskapsstatus og tilgjengelige data per i dag. Vi vil komme tilbake til dette senere, men først drøfte enkelte av de andre hovedmålsetningene i retningslinjene samt utvalgte temaer som ofte er fremme i debatten.

\section{Kartlegging og vurdering av selvmordsrisiko}

På tross av at dette temaet ikke egentlig var nytt i og med innføringen av retningslinjene, og heller ikke var særskilt vektlagt i disse i forhold til andre aspekter, er det svært stort fokus rundt dette, noe også resultatene av spørreundersøkelsen viste. Skillet mellom kartlegging og vurdering, som direktoratet besluttet å innføre, er ikke presist definert, og det åpner for ulike tolkninger og tilpasninger. Vi tror det er et blindspor å fokusere for mye på dette, da prediksjon av selvmord selv i høyrisikopopulasjoner som kjent ikke er mulig. Istedenfor tror vi at behandling av pasientens grunnlidelse, eller pasientens aktuelle problemer om man vil, bør komme enda mer i fokus.

\section{Kronisk suicidalitet}

Ikke minst gjelder dette behandling av pasienter med såkalt kronisk suicidalitet. Denne gruppa er allment akseptert som vanskeligere å nå med effektiv behandling, samtidig som de utløser mye bekymring blant terapeuter og pårørende og 
mange akutte tiltak, inkludert selvmordsrisikovurdering, med liten klinisk nytte på sikt. Denne gruppa ble derfor viet et eget avsnitt i retningslinjene, og vi tror at dette, sammen med bl.a. $\varnothing \mathrm{kt} \mathrm{kunnskap}$ om effektiv psykoterapeutisk behandling som for eksempel DBT og MBT, har bidratt til at disse pasientene kanskje nå i større grad får en mer adekvat vurdering og et mer tilpasset behandlingsopplegg. Det er imidlertid grunn til å tro at det på dette området er store lokale forskjeller.

\section{Oppfølging av pårørende og etterlatte}

Også evalueringen av denne hovedmålsetningen lider under mangelen på tilgjengelige systematiske data. Vi er ikke kjent med systematiske studier fra Norge med utgangspunkt i en psykisk helsevern-kontekst. Anekdotisk hører man stadig historier både med sterke negative, men også positive fortegn om pårørendes og etterlattes erfaringer. Tiden burde være overmoden for forskning på tiltak rettet mot disse gruppene.

\section{Gjøre helsepersonell mer kompetente, effektive og trygge}

Også på dette området mangler data for å gjøre en systematisk evaluering, med unntak av Sørums studie presentert i dette nummeret (Sørum 2012) av medarbeidere i såkalte akutteam på DPS. Flere forhold beskrevet over kan imidlertid tyde på at det nå omsider er langt mer fokus på vurdering og håndtering av suicidalitet i psykisk helsevern enn det var før retningslinjene trådte i kraft. Man kan imidlertid av og til undre seg over om den $\varnothing$ kte oppmerksomheten på feltet også har medf $\varnothing \mathrm{rt} \phi \mathrm{kt}$ usikkerhet. Både i vår løpende kliniske virksomhet og i undervisningssammenhenger ser vi stadige eksempler på at pasienters meddelelse av suicidale tanker kan medføre overilede, og derfor lite hensiktsmessige, tiltak som det ikke er kunnskapsmessig st $\varnothing$ tte for. Det er trolig vesentlig for feltet at vi ikke går for langt i å etablere en risikovurderingskultur på bekostning av effektiv helsehjelp rettet mot pasientens psykiske plager.
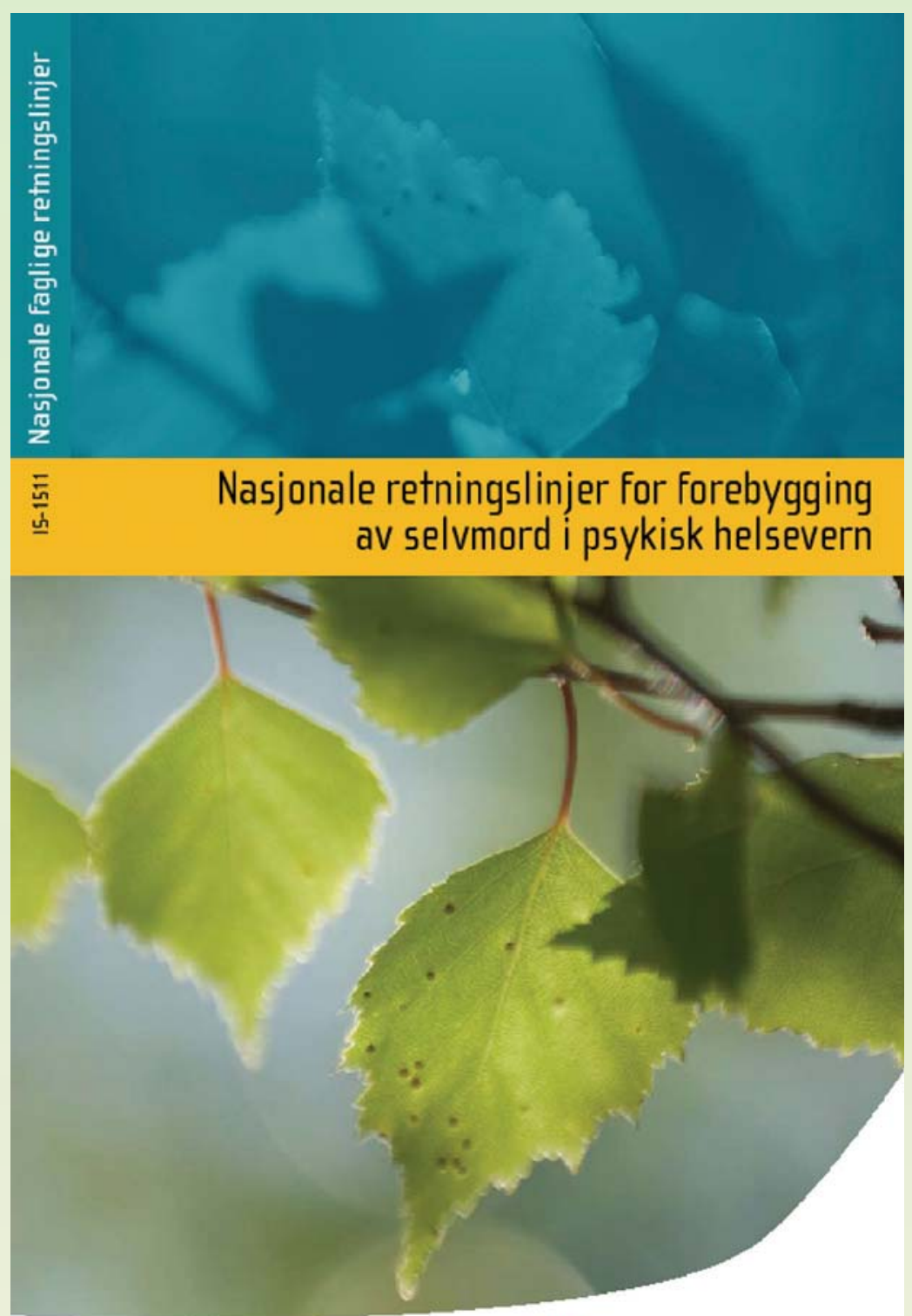

W 5osial- og helsedirektoratet

\section{Fra innholdet:}

- Kartlegging og vurdering av selvmordsrisiko

- Behandling

- Forebygging av selvmord i døgnenheter i psykisk helsevern

- Forebygging av selvmord etter utskrivning fra døgnenheter i psykisk helsevern

- Kronisk suicidalitet
- Ivaretakelse av pårørende og etterlatte

- Rapportering og oppfølging etter selvmord og alvorlige selvmordsfors $ø$.

- Rettslig grunnlag for helsehjelpen

- Kunnskapsoppsummeringene

- Begrensninger ved kunnskapsoppsummeringene

- Forslag til prosedyrer 
Når det er sagt, er det også på sin plass å minne om at fravær av adekvate selvmordsrisikovurderinger stadig er en gjenganger i tilsynssaker og ved fagrevisjoner.

\section{Fremtidige utfordringer}

Det er nå over fire år siden retningslinjene ble innført. Man kan derfor drøfte om tiden er moden for en revisjon. Vi tror det er for tidlig. Det er ikke tilkommet mye ny vesentlig kunnskap om effekt av intervensjoner, eller blitt dokumentert viktige nye risikofaktorer i denne populasjonen i disse årene, som skulle tilsi en snarlig revisjon. Det er imidlertid stadig en kunnskapsutvikling, kanskje særlig på intervensjonssiden, som bør overvåkes. Derimot mener vi å ha vist at den manglende løpende monitoreringen av omfanget og karakteristika ved selvmord som skjer i tilknytning til behandling i psykisk helsevern vanskeliggjør en evaluering av effekten av retningslinjene, med påfølgende problemer både for identifikasjon av områder med svikt og iverksetting av nye forebyggende tiltak. Vi mener derfor at utviklingen av et permanent granskningssystem for dette, etter modell av "The National Confidential Inquiry" i England og Wales (http://www.medicine.manchester.ac.u k/mentalhealth/research/suicide/preve ntion/nci/) bør ha høy prioritet i tiden fremover. NSSF har fătt i oppdrag av Helsedirektoratet å utrede mulighetene for en norsk tilpasning av denne tilnærmingen. Det foreligger en rapport basert på denne utredningen og en pilotstudie (Ness et. al 2011) som klart anbefaler en slik ordning.

Kunnskapssenteret er ansvarlig for en nasjonal kampanje med fokus på pasientsikkerhet, lansert for somatikken i 2011. Selvmord er sammen med overdoser tema innenfor psykisk helse og rusfeltet. I løpet av året vil det bli gjort pilotutprøvninger på kliniske avdelinger av tiltak som skal redusere forekomsten av overdoser og selvmord. Vi tror dette fokuset kan gi oss enda et nasjonalt løft på dette feltet, slik vi opplevde med retningslinjene i 2008 .

\section{Konklusjon}

Vi tror det er rimelig å konkludere med at utgivelsen av de Nasjonale retningslinjene for selvmordsforebygging i psykisk helsevern har medført en betydelig grad av $\varnothing \mathrm{kt}$ oppmerksomhet og forhåpentligvis mer fokus på problemet, tryggere helsetjenester og mer kompetanse blant helsepersonell. Dette er det imidlertid i liten grad mulig å dokumentere, og nettopp det er den viktigste utfordringen fremmover, og helt vesentlig for en videre utvikling av effektive selvmordsforebyggende tiltak i denne populasjonen.

Takk til Anita Kjølsrud (NSSF) for bistand med gjennomføringen av spørreundersøkelsen

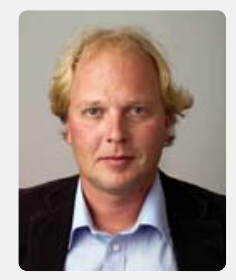

Fredrik A. Walby er forsker ved NSSF med en særlig interesse for selvmord og selvmordsforebygging blant pasienter med psykiske lidelser. Han har hovedstilling som sjefpsykolog ved

Voksenpsykiatrisk avdeling Vinderen, Diakonhjemmet Sykehus, og er jobber dessuten ved Psykiatrisk Legevakt i Oslo.

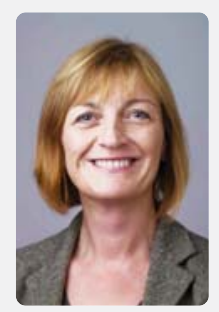

Ewa Ness er psykiater og fagsjef ved Klinikk for psykisk helse og avhengighet, Oslo Universitetssykehus og seniorrådgiver ved NSSF. Ness jobber også ved Psykiatrisk Legevakt i Oslo. Ness har i en årrekke ledet tjenesten ved Psykiatrisk

Legevakt i Oslo.

\section{Referanser}

Helsetilsynet (2012): Meldesentralen - oppsummeringsrapport 2008-2011. http://www. helsetilsynet.no/no/Publikasjoner/Rapport-fraHelsetilsynet/Rapport-Helsetilsynet 2012/Meldesentralen-oppsummeringsrapport-2008-2011/

Medisinalmeldingen (2010): Helsetilsynet i Oslo og Akershus. http://www.helsetilsynet.no/upload/ Publikasjoner/helsesosialmelding/oslo_og_akers hus_medisinalmelding_2010.pdf

Ness E., Walby, F.A., Mehlum, L. (2011):

Gransking av selvmord i det psykiske helsevern.

Pilotprosjekt. Rapport. Nasjonalt senter for selvmordsforskning og forebygging. http://www.med.uio.no/klinmed/forskning/sentr e/nssf/aktuelt/aktuellesaker/2012/Pilotrapport\%20 granskning.pdf

Qin P, Nordentoft M. (2005): Suicide risk in relation to psychiatric hospitalization: evidence based on longitudinal registers. Arch Gen Psychiatry. 62(4): 427-32.

Rønneberg U, Walby FA.(2008): Selvmord hos pasienter behandlet i psykisk helsevern. Tidssk Nor Lægeforen 2008; 128: 180-3.

Sosial- og helsedirektoratet (2008). Nasjonale retningslinjer for forebygging av selvmord i psykisk helsevern. (IS 1511/2008). Oslo: Sosial og helsedirektoratet. http://www. helsedirektoratet.no/publikasjoner/nasjonal-faglig-retningslinje-for-forebygging-av-selvmord-i-psykiskhelsevern/Sider/default.aspx

Sørum P.E. (2012): Selvmordsforebygging i akutteam ved DPS. Suicidologi: 17 (1): 3-6.

Walby, F.A. (2008); Faglige retningslinjer for forebygging av selvmord i psykisk helsevern. Suicidologi: 13(2): 6-9. http://www. med.uio.no/ klinmed/forskning/sentre/nssf/tidsskrift/2008/ nr2/Walby.pdf

Walby FA, Odegaard E, Mehlum L. (2006).

Psychiatric comorbidity may not predict suicide during and after hospitalization. A nested casecontrol study with blinded raters. J Affect Disord. 2006 Jun; 92(2-3): 253-60.

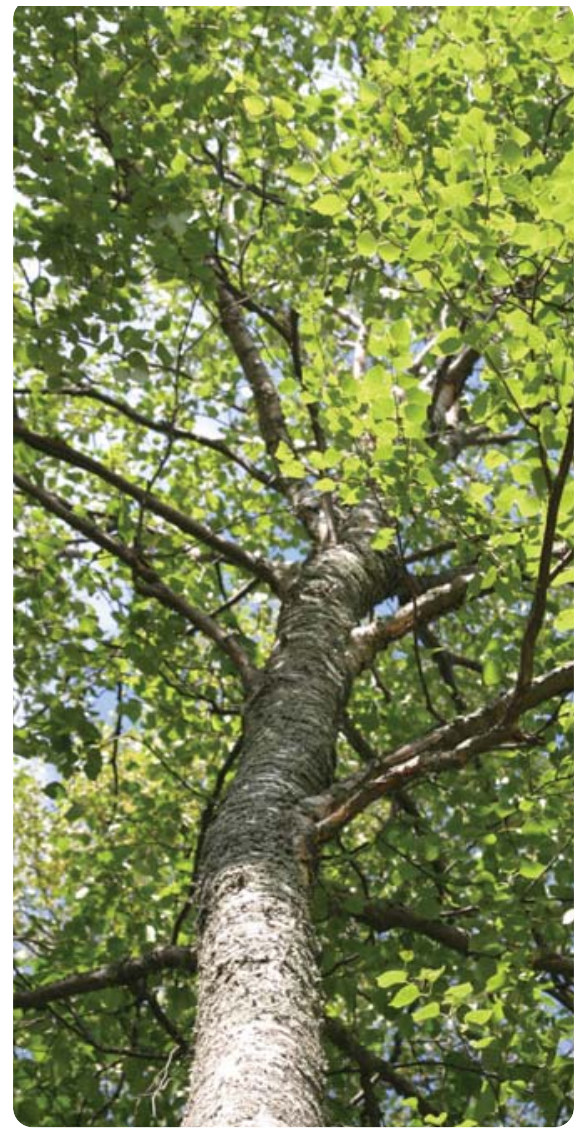

